\title{
The Patriotism of Gentlemen with Red Hair: European Jews and the Liberal State, 1789-1939
}

\author{
David Aberbach ${ }^{1,2}$
}

Published online: 20 March 2017

(C) The Author(s) 2017. This article is published with open access at Springerlink.com

\begin{abstract}
European Jewish history from 1789-1939 supports the view that construction of national identities even in secular liberal states was determined not only by modern considerations alone but also by ancient patterns of thought, behaviour and prejudice. Emancipation stimulated unprecedented patriotism, especially in wartime, as Jews strove to prove loyalty to their countries of citizenship. During World War I, even Zionists split along national lines, as did families and friends. Jewish patriotism was interchangeable with nationalism inasmuch as Jews identified themselves with national cultures. Although emancipation implied acceptance and an end to anti-Jewish prejudice in the modern liberal state, the kaleidoscopic variety of Jewish patriotism throughout Europe inadvertently undermined the idea of national identity and often provoked anti-Semitism. Even as loyal citizens of separate states, the Jews, however scattered, disunited and diverse, were made to feel, often unwillingly, that they were one people in exile.
\end{abstract}

Keywords Jewish history $\cdot$ Patriotism $\cdot$ Anti-Semitism $\cdot$ Nationalism $\cdot$ The liberal state

\section{Introduction}

The vast potential and fragility of the liberal democratic state after 1789, France above all, are highlighted in the patriotism of the European Jews from the French Revolution to the Holocaust. By offering emancipation and equal rights, the liberal state encouraged Jewish patriotism, of course, but anti-Semitism (often defined as 'genuine' patriotism) also spurred Jewish patriotism as a defence. European Jewish patriotism was one of the less expected consequences of the Enlightenment and the

David Aberbach

david.aberbach@mcgill.ca

1 Department of Jewish Studies, McGill University, 855 Sherbrooke Street West, Montreal H3A 2T7, Canada

2 London School of Economics, Department of International Development, London, UK 
French Revolution. ${ }^{1}$ The seeming implausibility of Macaulay's 'patriotism of gentlemen with red hair' - if men with red hair were persecuted as Jews were, Macaulay asked, could patriotism be expected of them $?^{2}$ - underlines Proust's caustic observation in À la Recherche du Temps Perdu that in France during the Dreyfus affair, 'the Jews showed, to the general astonishment, that they were patriots' (Les Juifs ayant, à l'étonnement général, montré qu'ils étaient patriots) (Proust 1992: ii 203). Jewish patriotism conflicted with the anti-Semitic stereotype-with the very definition of 'Jew' - and often this was the intent among increasing numbers of emancipated Jews determined to be accepted in their countries of citizenship by showing unswerving loyalty, though patriotism carried a host of meanings and motives, in different times and places.

This article argues that European attitudes toward emancipated Jews in the century and a half after the French Revolution support the view that construction of national identities even in secular liberal states was determined not only by modern considerations alone but also by ancient patterns of thought, behaviour and prejudice. ${ }^{3}$ While emancipation implied acceptance, consequent Jewish patriotic identification with the state and national culture was automatically suspect. Jewish patriotism often roused alarm and suspicion as Jews were the archetypal 'Other', for centuries scattered throughout Europe, their only true home the land of Israel. Prior to 1789, Jews were commonly blamed for their stubborn refusal to assimilate into Christian Europe. With the rise of nationalism and the secular state after 1789, the reverse was true. Jews were increasingly eager to embrace a variety of patriotisms and national cultures throughout Europe, even with the end result of renunciation of Judaism and conversion to Christianity. However, this newfound willingness to adapt and assimilate riled nationalists who saw authentic ethnicity as exclusive of Jews. As European antiSemitism grew, Jewish patriotism in a kaleidoscopic variety of countries was often met with scorn and hate. A paradoxical result was that especially in Western Europe many Jews struggling in the direction of assimilation into their countries of citizenship were dragged against their will in the opposite direction: to be part of a persecuted Jewish nation.

With the spread of nationalism and national conflict in the nineteenth century, patriotism became an almost inescapable duty, expressed through civil, political and national loyalties and army service, as well as linguistic and cultural bonds. Even dissenting ideologies, such as Zionism in Imperial Germany or socialism in Tsarist Russia, were often asserted in language of patriotic loyalty and love, with national rather than Jewish interests predominant. By the early twentieth century, Jews had strong political, economic and cultural ties to every major European state, and many minor ones, including countries that distrusted, hated and fought one another. The full incongruity of Jewish patriotism even in relatively liberal states became clear, as we shall see, in World War I.

\footnotetext{
${ }_{1}^{1}$ For a full-length study of European Jewish patriotism, with bibliography, see Aberbach (2013).

2 In 'Civil Disabilities of the Jews' (1831) (Macaulay 1963: 122).

${ }^{3}$ The view that nations have ancient 'navels' is argued among others by Seton-Watson (1977), Armstrong (1982), Hutchinson (1987) and Smith (1991). For the opposing view, of nationalism as a modern phenomenon, see for example Kedourie (1960), Gellner (1983), Deutsch (1966), Anderson (1991) and Hobsbawm (1990).
} 


\section{Emancipation and Jewish Patriotism}

How did emancipation and hope of emancipation foster patriotism, even in anti-Semitic countries such as Tsarist Russia? ${ }^{4}$ Emancipation began in America after its war of independence against Britain when the Virginia Act (1785), framed by Thomas Jefferson and influenced by the French Enlightenment, established the principle of religious freedom and the removal of religious restrictions to citizenship, and the Constitution of the United States of America (1789) guaranteed legal equality for all American citizens. Then, as part of the French Revolution, came Jewish emancipation in France (1791) and, during the Napoleonic Wars, in all lands conquered by France, including Belgium, the Netherlands, southern Germany and Italy, and after France's defeat in 1815, with the spread of emancipation throughout Europe, despite anti-Jewish backtracking and reluctance. The upheavals of 1848-1849-in which Jews took part in revolts in France, Prussia and the German states, Italy, Austria, Hungary, Bohemia, Polish territories, Galicia and the Grand Duchy of Poznan - convinced many Jews, especially in Western Europe, that 'political involvement would promote their civic emancipation' (Eisenbach 1991: 353), and although the 1848-1849 revolts were marked by widespread pogroms, it seemed a new era had begun, in which Jews 'would be accepted by their peers simply as human beings'(Reinharz 1975: 8). The momentum of emancipation continued: in England by 1858 and as part of the unification of Italy and Austro-Hungary in the 1860s and finally, Germany in 1871. Russia emancipated its Jews only after the February (March) 1917 revolution deposed the Tsarist regime.

Emancipated Jews had every reason to be patriotic, insofar as the post-1789 liberal state promoted equality, rights, tolerance, religious liberty, secular education, progress, modernity, professional training and advancement, and upward social mobility. Patriotism was a natural expression of thanks for the revolutionary changes brought by emancipation - all the more so in view of the relatively backward conditions and low status of the Jews prior to 1789. Many Jews, believing that the 'true' nation was dedicated to internationalist ideals of freedom, justice and equality, refused to see themselves as anything other than citizens of France, Holland, Italy, Hungary, Romania, Poland and elsewhere and remained loyal to the state. Even in anti-Semitic Tsarist Russia Jews could hope either for growing liberalism through a constitutional government or for socialist revolution and the international liberation of oppressed peoples (Frankel 1981).

Jewish patriotism belonged to a behavioural code, a strategic tactic, an adaptive process or perhaps even a survival mechanism. In Russia, the rabbis recited a prayer for the anti-Semitic Tsar Nicholas II, yet as Leon Poliakov points out in History of Anti-Semitism, ' ... there is no certainty that the rabbi who chanted the official prayer for the tsar harbored a lesser hatred in his heart than the most extreme bombthrower or propagandist' (1985: 4, 101). In Germany, too, 'Jews only rarely uttered their political views in a straightforward manner' (Sieg 2003: 215). Different Jewish groups had different perspectives, depending on their roles: it was expected, for example, that communal leaders would represent their communities in a patriotic light and do so sincerely even when faced with anti-Semitism. Jewish (and formerly Jewish) writers and thinkers, such as Heine, Marx, Freud, Durkheim, Buber and Weil, expressed an entire spectrum of patriotism (particularly in wartime) while often claiming for their work and

\footnotetext{
${ }^{4}$ On the 'maskilic tendency toward patriotism', see Feiner (2002). For comparative studies of emancipation and nation building among Jewish, Catholic and Protestant minorities, with chronological details, see Liedtke and Wendehorst (1999).
} 
ideas universal significance. Yet others, including Arnold Döblin, Lion Feuchtwanger, Franz Kafka, Arthur Schnitzler, Ernst Toller, Jakob Wassermann, Joseph Roth and Franz Werfel, though generally attached to their countries, wrote works which in various ways questioned the wisdom of Jewish loyalty to countries that hated them. Kafka's The Castle, for example, was written after the anti-Jewish riots in Prague in 1920 partly as a critique of the failings of emancipation, of its fundamental ambivalence and the illusory quality of the rights it conferred. Kafka's own response to anti-Semitism was an increased sympathy with Zionism. At the time of his death in 1924, he was studying Hebrew and planning to emigrate to the land of Israel.

Hebrew writers, such as Ahad Ha'am (pen name of Asher Ginsberg (1856-1927), C.N. Bialik (1873-1934), S.Y. Agnon (1888-1970) and U.Z. Greenberg (1896-1981), writing as Zionists for a Jewish readership, were less susceptible to the traps of patriotism. They felt free to attack European Jewish patriotism as a form of national suicide. Anti-Semitism in their view was too deeply rooted in Europe to allow genuine Jewish assimilation. Ahad Ha'am argued that the French Jews were deluded by the hope of 'la fusion sociale.' Their freedom was shallow, disguising moral bondage: 'Do I envy the rights of [the French Jews]?... Absolutely not' (Ha'am 1953: 68). Declaring his preference for Russian servitude over French emancipation, Ahad Ha'am insists that in autocratic Russia, he has freedom more valuable than French revolutionary liberté. He has freedom to love the Jewish people and Jewish culture without being accused of lack of patriotism: 'Though I have no rights [in Russia], I haven't sold my soul for them... I would not exchange my spiritual freedom for all the rights in the world' (ibid, 68-9). Ahad Ha'am's views are echoed in a Hebrew poem by his disciple Bialik, published in 1904, depicting the Jewish struggle for assimilation in the language of unloving sexual relations, a form of prostitution, as these Jews sank their lives into the 'bosom of alien stone' and sacrificed their energy and imagination to hostile peoples: 'as your flesh drips blood between the teeth of your destroyers - / you'll feed them your soul' (Bialik 2004: 102). Such frankness was more frequent in Hebrew and Yiddish, aimed almost exclusively at Jews, than, say, in French, German or Russian.

Jewish patriotism was multifaceted, unusually complex in historical, sociological and psychological causes and consequences throughout Europe from 1789-1939. ${ }^{5}$ An unprecedented population explosion lifted the worldwide Jewish population to its highest level in history, from an estimated three million in 1800 to nearly seventeen million in 1939. Jewish patriotism in different countries and societies at different times had chameleon meanings: the explosive release of Jewish talent and enterprise which came with emancipation, civil rights and unprecedented opportunity, upward mobility and prosperity (in Central and Western Europe); willingness to join non-Jews in a civic, secular, tolerant society, at times an edge of almost hysterical anxiety to belong; the fear and vulnerability of a threatened minority whose emancipation was not approved by the largely anti-Semitic European masses, yet which was increasingly uprooting itself from its often-denigrated religious culture. In reaction to antiSemitism, Jewish patriotism could express Jewish self-hate; though at times there was also, perhaps, an element of resistance or subversion in Jewish patriotism toward anti-Semitic countries: the state, guilty of unreasoning hatred, wanted to drive Jews away, but they held their ground, upholding the liberal ideals of the 'good' state. As in a pathological marriage in which one partner is violent and the other passive, Jewish passive loyalty could exacerbate

\footnotetext{
${ }^{5}$ On patriotism, see Habermas (1992), Viroli (1995), Cohen (1996) and Doob (2004). In the case of the Jews, the word 'patriotism' or 'patriotic' generally means loyalty to the state; though the word 'nationalism' or 'nationalist' is also apt as Jews often developed deep identification with national cultures, a tendency which led to much resentment on the part of the Christian population whose ethno-nationalism excluded Jews. See Connor (1994) and Hastings (1997).
} 
anti-Semitic hatred and violence. ${ }^{6}$ Yet, patriotism could also express what Fritz Stern (1987: 114) describes as 'a great flowering of the human spirit and imagination'.

Patriotism often accompanied pride in and high valuation of Judaism and commitment to the struggle to transform Judaism and make it viable and presentable in increasingly secularized societies. Patriotism could be regarded either as compatible or incompatible with Jewish difference and Jewish international solidarity. Patriotism could express the great surge of hope that, with emancipation, Jews had broken utterly with their lachrymose history of persecution, discrimination and hatred, but their patriotism was also consistent with the Jews' history of loyalty to countries that — as was the case for long periods — treated them well. ${ }^{7}$ Patriotism could reflect admirable loyalty and justifiable hope of acceptance or abject servility, mindboggling blindness and perverse attachment to countries that were no motherland but, in the end, a killing ground and a grave.

Modernized Judaism evolved largely in adaptation to the sacred ideals of state-based nationalism. In nineteenth-century Germany, patriotic Reform Jews, wishing to avoid a conflict of loyalty and convinced that their enlightened German identity made some of their ancient traditions obsolete, removed prayers for the return to Zion from their prayer books (Aberbach 2006). Some Jews saw citizenship as a new identity, an escape from the anguish of a seemingly outmoded, scarred and vulnerable Jewish way of life. Others stressed their patriotism to protest against (or deny) Judaeophobia and the failure to gain acceptance in Christian society. Increasingly, Western and Central European Jews stopped thinking of themselves exclusively as religious exiles from the land of Israel awaiting messianic redemption. As citizens, they were 'at home'. For the first time, they put national allegiances above traditional worldwide Jewish religious solidarity. Having no national territory and often repulsed by their exclusivist Talmud-based orthodox rabbinic heritage, they were eager to fight and die for the fatherland — even when the enemy included other Jews. For this reason, in World War I 'German Jews fought and died as German patriots, shooting at British Jews who served and fell as British patriots' (Gilbert 1987: 21). On a much larger scale, the Jews of Austria-Hungary and the Jews of Russia fought and killed each other while serving their respective fatherlands. ${ }^{8}$ Despite their patriotism and sacrifice, Jews in all the belligerent countries were accused of wanting 'to slaughter the fatherland' (Poliakov 1985: iv 26, 148).

Rapidly growing secular school systems in the nineteenth and early twentieth-century Europe prepared Jewish children to enter the mainstream of European culture and served as conduits of patriotism, whether they or their parents liked it or not: German Jewish children were taught to be grateful to the Kaiser because 'the Kaiser's heart envelops all his subjects in equal love' (Kaplan 1992: 59), while Polish Jewish children were taught an exceptionally beautiful picture of Poland 'through the images of the Romantic Polish poets' (Heller 1977: 224); French schools inculcated both the universalist ideals of the Revolution and more narrowly nationalist identification with 'our ancestors the Gauls' (Arendt 2007: 271).

Patriotic loyalties held Jewish organizations back from working together to fight antiSemitism. Insofar as Jewish organizations such as the official communal representative of German Jewry, the C.V. (Centralverein deutscher Staatsburger jüdischen Glaubens),

\footnotetext{
${ }^{6}$ On the theme of unrequited love in pre-1939 Jewish literature, at times with openly allegorical intent, referring to Jewish patriotic love for the fatherland and its unhappy consequences, see Aberbach (2013: ch. 9; with particular reference to Germany, 2015).

${ }^{7}$ Classic Hebrew texts frequently cited to encourage and justify patriotism are in the Bible (Jeremiah 29: 1-7), and the Mishna (Ethics of the Fathers iii 2).

${ }^{8}$ During World War I, even Zionists were divided along national lines: for example, while Chaim Weizmann worked as a scientist for the British Admiralty, Nahum Goldmann worked as a propagandist for the German Foreign Office. For a detailed discussion of Zionist patriotism, with sources, see Aberbach (2009a).
} 
fought anti-Semitism, they generally did so in a spirit of patriotism for the ideal state intolerant of prejudice, in the belief that ancient hatred could be overcome, integration was possible, patriotism justified and emigration unnecessary. For Jewish organizations to respond to anti-Semitism by acting decisively for Jewish interests, if necessary with organized emigration to safer countries, was to admit the possibility that the Jewish communities they served were living a lie; their emotional investment in countries that hated them, a lethal blunder; their trust in reason and progress, misplaced; their successes deceptive, their hopes futile and their emancipation a grand illusion.

In different countries at different times, the meaning of Jewish patriotism changed, drastically at times. The enthusiastic patriotism of Prussian Jews in 1812, of Hungarian Jews in 1848-1849 or Polish Jews in 1863 was not the same as the desperate patriotism of German, Polish and Hungarian Jews as their world collapsed in the 1930s and early 1940s. Patriotism of emancipated Jews in Western Europe - in France and England, for example-reflected gratitude for what had been granted, whereas patriotism among Russian Jews under Tsarist rule was encouraged by the efforts of the regime, however anti-Semitic, to modernize its Jewish population (Nathans 2002). Jewish patriotism changed, too, as European nationalism moved in the nineteenth century from the Left to the Right on the political spectrum. The patriotism of assimilated Jews had a different character from that of orthodox Jews, whose patriotism was limited by their messianic hopes. In Germany, the patriotism of Jewish men, particularly war veterans, was greater than that of their wives (Kaplan 1998: 65-6). The militant patriotism for Germany, say, of Berthold Auerbach at the time of the Franco-Prussian War of 1870-1871-Auerbach supported the annexation of Alsace-Lorraine-contrasted with the pacifist Austrian patriotism of Stefan Zweig, based on love for German culture. The patriotism of Jewish factory workers was not the same as that of Jewish communal officials or soldiers-or children often doubly indoctrinated, at home by their parents and at school by their teachers. The patriotism of Jews in independent democratic states differed from that of Jews in totalitarian counties. The patriotism of Ashkenazic Jews differed in some ways from that of the far less numerous European Sephardic Jews. The patriotism of British Jews was encouraged by the association of Jewish rights with Victorian humanitarianism and the valuation of religious liberty; the patriotism of German Jews in the late nineteenth and early twentieth centuries was driven both by a profound identification with German Kultur and recognition that they were not fully accepted as citizens and members of the Nation: in Germany, the word 'patriotism' 'frequently implied considerable anti-Semitic feeling' (Kaplan 1992: 201); the patriotism of Italian Jews generally expressed conviction that they were welcomed as an integral part of Italian society; ${ }^{9}$ the patriotism of Greek Jews reflected the struggle between Greece and Ottoman Turkey, with preference for Turkey; the patriotism of Czech Jews was ensured by a tolerant government policy; the patriotism of Jews in Holland reflected confidence of a highly assimilated community emancipated as early as 1796. The patriotism of French Jews at the time of the Dreyfus case (and, later, even during the Vichy regime) was inspired by love of the 'true' France, the France of revolutionary ideals, the first European country to emancipate its Jews (in 1791) and which had emancipated the Jews in the lands of its conquests in the Napoleonic Wars: France, with its revolutionary tradition of state

\footnotetext{
${ }^{9}$ The Jews of Rome when liberated from their ghetto in 1870 announced to King Victor Emmanuel that they would from now on be Italian and Romans and nothing else (Dubnow vol. 5, 1973: 371).
} 
secularism and education, and the universalism of the Rights of Man, would never betray its own loyal citizens.

Jewish patriotism was a constant - even when political circumstances made it hard for Jewish communities to decide on the object of their loyalty. The Dutch Jews under French revolutionary rule at the time of their emancipation in 1796 were divided in their patriotism. Some supported the revolution and others the Dutch monarchy: "Although an energetic minority of Jews, notably those gathered in the Amsterdam club "Felix Libertate," had busied themselves in the Patriot cause and shown themselves eager to propagate the ideals of the revolution amongst their co-religionists, the mass of their people were generally thought of, especially among the petty-burghers, as fierce supporters of the House of Orange' (Schama 2005: 262). Similarly, Hungarian Jews who identified with the Magyars alienated nonMagyars; Jews in Greece were torn between Greece and Turkey. ${ }^{10}$ Jewish involvement in the Hungarian revolt against Austria in 1848 created anti-Jewish hostility among Croats and Serbs, who fought on Austria's side; in Bohemia, Jewish support for the Czechs antagonized the Germans, and Jewish support for the Germans created friction with the Czechs. Conflicting patriotic loyalties often undermined family relationships and friendships - even among orthodox Jews and Zionists. Traditional Jewish patriotism for Zion became in some cases a template for the new secular patriotism. European Jews began to abandon faith in their traditional Zion, based on the Hebrew Bible, the Talmud and siddur, and adopted a new faith in the 'Zion' of the countries that emancipated them, including countries with anti-Semitic tendencies, such as France and Germany.

The large numbers of Eastern Europeans Jews who migrated westward, especially within the Habsburg empire which linked the East to the West, generally found that they had more freedom and rights and better prospects than in their places of origin. Many sought rapid cultural assimilation and raised their children to feel at home with the new culture, sending them to schools which were often excellent preparations for professional life, with strong patriotic content. The second or third generation usually had no other culture: they were French, German or Italian, etc. by upbringing and could be nothing else. When Jews heard anti-Semites abusing them in their native languages, they did not and could not easily renounce these languages. Yiddish and Hebrew tended to decline with emigration, though socialism and Zionism opened up new possibilities for these languages. Hebrew was of course read daily by millions of Jews, mostly in Eastern Europe, as the language of the Bible and prayer, but Jewish religiouscultural loyalty was historically compatible with attachment to countries in the diaspora. ${ }^{11}$ Patriotic loyalty was often linked to a deep affection for landscape and culture, particularly in Germany. The German Jewish writer, Ernst Toller, recalled ruefully his naïve youthful love for Germany and, as for the German language, was it not 'the language in which I feel and think and speak, a part of my very being?' (Toller 1934: 281). Yet, in Eastern Europe, too, patriotic sentiments and cultural attachments tended to grow, despite anti-Semitism. Romanian Jews, for example, though hated and persecuted, still hoped that they had a future in Romania. Their resistance to organized

\footnotetext{
${ }^{10}$ See Zweig (2002) and Fleming (2008). Prior to the collapse of the Ottoman empire in World War I, Jews living in Greek lands tended to be pro-Turkish as Muslim rule was more tolerant towards the Jews than Christian rule. During the uprisings in Crete in 1897, thousands of Jews in Salonika, then under Turkish rule, marched in the streets chanting, 'We would rather die than give Crete to the Greeks' (ibid, 56). After the Balkan Wars of 1912-1913, when Salonika was annexed by Greece, Jews looked to Athens as a place to 'assert their Greekness' (ibid, 47).

${ }^{11}$ See note 7 above.
} 
emigration in the interwar years was summed up by Horia Carp, a delegate of the Union of Romanian Jews to the Romanian senate: 'we have no other political aspirations than those of the Romanian people' (Mendelsohn 1983: 190).

Citizenship inspired Jewish patriotism as part of a new identity, or the promise of one, an escape from Judaism and the Jewish community. Many Jews hoped that citizenship would give them an impenetrable shell freeing them of their own alleged defects and weaknesses as Jews, a new civic or even national identity, strong, confident, progressive, liberal, tolerant, far preferable in theory to their own crumbling tradition, as they often saw it. Others regarded patriotism as compatible with Jewish pride or stressed their patriotism to protest against (or deny) Judaeophobia and the failure to gain acceptance in Christian society or to fight the anti-Semitic claim that they were incorrigibly disloyal. The lack of territory was an incentive to patriotism, among Polish Jews for example (Weinbaum 1993: 5) or Austrian Jews who found that the Treaty of Versailles isolated and made them 'true patriots - professional Austrians, almost' and more vulnerable than before (Zohn 1985: 139-40) or Italian Jews, having had no territory of their own or ties of loyalty to the anti-Jewish aristocratic and Catholic regimes that became unified in the Risorgimento, who 'felt more Italian than the Italians... [and] served the cause of Italian nationalism unconditionally, working for the creation of a new 'fatherland' in which they could feel equal to others' (Segré 1988: 19-20). In Germany, however, anti-Semites pointed to the insistence of Jews that they were Germans first and foremost-while non-Jews generally identified themselves as Prussians, Bavarians, Saxons, Württemburgers, etc.-as 'the best proof' that they were nothing other than Jews (Frister 2002: 127). All that German Jews did for Germany and German culture 'failed to silence the reiterated accusation of lack of Jewish patriotism' (Baron 1962: 19). ${ }^{12}$

The German Jews are often seen as extreme patriots; in fact, they were not untypical of European Jews generally. The Centralverein was not uncharacteristic of Jewish organizations throughout Europe: in its loyalty to the state, its promotion of cultural 'symbiosis', its encouragement of Jewish patriotism and the 'cultivation of German conviction' (Pflege deutscher Gesinnung), and in its wariness of involvement with Jews in other countries, even when emergency aid was needed. Even during the Holocaust, there were German Jews such as Victor Klemperer who clung to the belief that 'The German Jews were part of the German nation' (2000: 279) ${ }^{13}$ and tried desperately to stay German and in Germany. The next pages give a brief sketch of Jewish patriotism in Western and Eastern Europe, ${ }^{14}$ whose exceptional variety could itself cast into doubt Jewish patriotism to any one country.

\footnotetext{
${ }^{12}$ The charge of Jewish unpatriotism was frequently used to justify German Jew-hatred,yet, owing to the late development of the German state, German patriotism was slow to develop: during the Napoleonic period, 'German patriotism was marginal' (Breuilly 1992: 8).

13 "The "fourth Reich" that established itself in Hampstead and Washington Heights, in Hollywood and Nahariyah, with battered tomes of Lessing, Kant and Goethe and the scratched records of Furtwangler and the Threepenny Opera, bore witness to the tenacity of roots in the German Kulturnation' (Pulzer 1992: 350). Among the surviving Jews in Germany after the war, George Mikes observed in 1952 that many were 'ardent German patriots' (Mikes 1958: 93).

${ }^{14}$ For more details on individual countries, with fuller bibliography, see Aberbach (2013).
} 


\section{Jewish Patriotism in Western Europe}

\section{France}

The patriotism of the European Jews toward the modern liberal secular state began in France after emancipation in 1791. From then on, the relatively small French Jewish community of about 40,000 set the patriotic tone for other European Jewish communities. French revolutionary ideals led the way in Europe, and the French Jews remained devoted to la patrie, which 'put an end to the long exile' (Berkovitz 1989: 245-46). Assimilation became practically the doctrine of the Jewish community (Zeldin 1977: 1036, 1037). The native French Jewish leadership, in its fierce love for France and French culture, was at times 'blinded' from seeing dangers posed by anti-liberal and nationalist forces (Hyman 1979: 202). There were more antiSemitic publications in France than anywhere else, and in France, anti-Semitism was most articulate and all pervasive (Ferguson 2000: 260, 262; Golsan 2010). Many French Jews came to believe in a mutually enriching 'symbiosis' of French and Jewish civilizations, and their leaders in particular saw their Frenchness and their Jewishness as 'fundamentally intertwined' (Leff 2006: 229). The French Jewish community was in the avant garde of European Jewry in its modernisation, its patriotism and in dealing with problems arising from emancipation. Though some French Jews felt that anti-Semitism was 'as French as apple pie... as natural as the turn of the seasons' (Weber 1985: 10), they had reason to believe, nevertheless, that they were on the path to genuine integration, sharing France's destiny. ${ }^{15}$

Jewish patriotism survived Drumont's anti-Semitic La France Juive (1886), the bestselling book in late nineteenth-century France, and the Dreyfus affair exposing virulent anti-Semitism throughout French society. Even on Devil's Island, Dreyfus pledged undying loyalty to la patrie and to the French army that ruined his life (Burns 1999: 175). Many French Jews believed that the Dreyfus case vindicated faith in republicanism, in 'the true France'. Even under the collaborationist Vichy government (1940-1944) which instituted racial laws and sent tens of thousands of Jews to Auschwitz, French Jewry, including many Zionists, refused to see itself as anything but French, remaining loyal to the state-obedient even to its antiSemitic laws (Adler 1987: 226). ${ }^{16}$

\section{England and Disraeli}

In England, emancipation, though gradual, was more successful than elsewhere in Europe, and English Jews generally felt that their patriotism, though distorted at times by anti-Semitism, was justified. As a British patriot, Benjamin Disraeli (1804-1881)though a convert and an alien figure-was characteristic of the community into which he was born. While Disraeli's beliefs, feelings and motives were often enigmatic, his patriotic faith in Britain was unquestionable (Hibbert 2004: 362-63). Disraeli's political career would have been impossible had his father not had him converted in 1816, at age 12 ; even so, he suffered continual abuse as a Jew. In his early years in parliament, he wrote to the newly appointed prime minister, Robert Peel, in 1841, 'I have tried to

\footnotetext{
${ }_{15}$ See, for example, Hyman (1979: 9), Winock (1998: 104), Marrus (1980: 91, 118) and Aberbach (2013: 172).

${ }^{16}$ The 'savagely committed patriotism' of the French Jewish philosopher, Simone Weil, possibly 'shaped her destiny more deeply than that of any twentieth-century writer' (Plessix Gray, Francine 2001: 10). Her death in 1943 was practically a patriotic suicide: she died 'of patriotism, out of sorrow and shame for the fate of France' (ibid, 207).
} 
struggle against a storm of political hate and malice which few men ever experienced' (Blake 1967: 164). Disraeli's efforts in 1847 to persuade parliament to remove the civil disabilities of the Jews exposed deep-rooted prejudice, even among liberals: 'High Tories were prepared to meet an argument based on toleration, not one based on the view that the Jewish religion was nearly as good as Christianity' (ibid, 269). As elsewhere in Europe, opponents of emancipation argued that England was a Christian state and should remain so. Among countless slurs, Thomas Carlyle referred to Disraeli as 'a cursed old Jew, not worth his weight in cold bacon' (ibid, 552). Still, Disraeli seems never to have regretted his patriotism. In contrast with Continental Europe, Jews in England were not subject to periodic obsessive public concern as a moral, social or political threat nor until the Aliens Act of 1905 (which did not refer specifically to Jews) were they targeted for restrictive legislation: 'anti-Semitism was neither as virulent or explosive as in other European states nor as successful in derailing Jewish integration' (Endelman 2002: 162). In the Victorian age, Jewish difference was tolerated to an extent, as was Jewish internationalism exemplified by Moses Montefiore (Green 2010), though Jewish aid to persecuted and impoverished Jews overseas laid them open to the charges of clannishness and international conspiracy. Also, unlike right wing parties in Continental Europe, the English Conservative party, despite its anti-Semitic elements, rejected official antiSemitism, the revocation of emancipation and social exclusion of Jews, and from the 1870 s propertied Jews actually began to vote for and even to fund the Conservative party (Endelman 2002: 166).

As was the case throughout Europe, in 1914, Jews in England responded to the war with enthusiastic patriotism. About $90 \%$ of young men from native Anglo-Jewish families volunteered before conscription began in 1916, yet their patriotism was uneasy: 'wartime Germanophobia and renewed xenophobia nourished old hostilities, which, it was feared, would end in anti-Semitic violence' (ibid, 183-84).

\section{Germany}

Especially in wartime, the requirement of German patriotic loyalty tended to silence dissenting voices such as that of Gershom Scholem, who once told me how his refusal to serve in the German army in World War I led to his eviction from his family home in Berlin (Aberbach 2013: xviii). Imperial Germany, despite rapid modernization, did not encourage an ideology of multiculturalism, rather of the assimilation of 'foreign' groups, including Jews. Germans could not easily accept Jewish patriotism as genuine, being suspicious of the loyalty and trustworthiness of the Jews who, for their part, never tired of demonstrating the depth and extent of their patriotism (Volkov 2006: 118, 194, 252). ${ }^{17}$ German Jewish patriotism was taken to an extreme form by the industrialist and politician, Walther Rathenau. Rathenau demanded of the Jewish people a form of national suicide, 'a shedding of tribal attributes', total eradication of everything Jewish and total identification with the Aryan Nordic heroic spirit. ${ }^{18}$ Rathenau had

\footnotetext{
${ }^{17}$ Notable examples of passionate devotion to Germany are Heine (a convert to Christianity) _ 'I am one of the most German of creatures... At bottom I love what is German more than anything in the world' (in Prawer 1983: 209) and the nineteenth century Jewish politician Gabriel Riesser, who claimed that anyone who disputed his German identity deprived him of 'my very right to existence' and had to be fought as though he was a murderer (Laqueur 2003: 8). Within the German Jewish population, such patriotism was not unusual.

${ }^{18}$ For Rathenau's essay 'Höre Israel' (1897), calling for mass conversion of German Jews, see Mendes-Flohr and Reinharz (1995: 267-8). The Nazis made this essay required reading in German schools.
} 
few illusions about his inferior place as a Jew in German society, yet he believed that 'My people are the Germans and no one else. The Jews are for me a branch of the German nation [ein deutscher Stamm] like the Saxons, Bavarians or Wends' (Joll 1960: 65, 66). Others, such as writers Ernst Toller and Jakob Wassermann, felt their patriotism crumbling under the pressure of anti-Semitism. Toller (1934: 281) recalled in his autobiography that as a young man he had loved Germany with all his heart. Even amid the rich beauty of the Mediterranean he had longed for Germany, its pinewoods and lakes. Yet, German anti-Semitism destroyed his uncritical love of Germany. Jakob Wassermann, too, began as a German patriot. As antiSemitism grew, he found himself echoing Herzl's cri de coeur in Der Judenstaat that the Jews were patriots in vain. ${ }^{19}$

German Zionist leaders, notably Moritz Goldstein and Franz Oppenheimer, fought to curb their love for German culture and zeal for German/Jewish 'symbiosis'. Goldstein in 1912 warned that German Jews were playing with fire by administering the spiritual heritage of a hostile people. Like a hapless suitor who must overcome his crippling passion and devotion, the Jews must tear themselves from Germany. ${ }^{20}$ Oppenheimer, a sociologist, concluded that it was futile to present anti-Semites with evidence that they were wrong: 'It doesn't matter,' they would respond. 'The Jew must burn' (Dwork and van Pelt 2002: 33). Yet, Oppenheimer never overcame his devotion to Germany: 'Germany is my fatherland, my homeland, the land of all my yearnings, the land in which my forefathers have been buried, the land of my battles and my love, and when I return home from a foreign country I come home... to Germany...' (Reinharz 1975: 129-30, 143).

World War I temporarily pushed aside the question whether or not German Jews should remain loyal to an anti-Semitic country. German Jewish patriotism overrode anti-Semitism and the feeling that, as Ernst Simon put it, 'we were strangers... we did not belong' (Friedländer 1997: 75). Even German Zionists in Palestine had a 'highly developed sense of duty to Germany' (Zechlin 1969: 90, note 34), and some volunteered to fight for Germany. After the War, the main opposition to the pro-Zionist Weimar German government policy came from the C.V., which still regarded Zionism as 'un-German' and feared that a Jewish state might lead to anti-Semitic pressure to expel the German Jews (Poppel 1976: 116).

\section{Holland, Italy and Austria-Hungary}

Various forms of patriotism typified Jewish communities elsewhere in Europe. The faith of Dutch Jews in Holland - 'Our fatherland is the promised land'(Fuks-Mansfield 2002: 209)was that of a highly assimilated, modernised community. The Dutch historian, Judith C.E. Belinfante, describes the typical Dutch Jew as above all 'a loyal subject of the Dutch state': trust in the state 'blinded' many Dutch Jews to the full meaning of its collaboration in the Holocaust (Chesnoff 1999: 82-3). The low-key nature of Dutch anti-Semitism increased Jewish vulnerability (Blom 2002: 223-4). Few predicted that Holland would adopt Nazi racial laws, or that Dutch municipal administrations, railway workers and police would collaborate in the extermination and plunder of Dutch Jewry as the Dutch government-in-exile (including Queen Wilhelmina) remained silent, facilitating the murder of about 125,000 Jews, or that many of the 15,000 Dutch Jews who survived would be treated cruelly on their return. Yet,

${ }_{19}$ On the alleged futility of Jewish patriotism, compare Wassermann (1921: 122-3) with Herzl (1896: 11).
20 'Das Verhältnis der Juden zu Deutschland aber ist das einer unglücklichen Liebe' (in Albanis 2002: 83). 
their patriotism was not totally unvindicated: about 20,000 Dutch men and women risked their lives to shelter Jews during the war.

Among Italian Jews, patriotism was practically a religious duty. As in Germany, their emancipation came with unification, but patriotism seemed more justified than in Germany. Italian anti-Semitism outside the Church was weak. The Italian Jews, never more than $0.2 \%$ of the total population, had little attachment to the aristocratic and Catholic regimes of the Italian states which had segregated them. The Jews served with unconditional loyalty and enthusiasm the cause of a new Italian nation in which they would be equal to other Italians. After 1860, hardly any country in Europe offered Jews better conditions than Italy. Until 1938, the Italian Jews had full civil rights, were thoroughly assimilated and saw themselves as Italians first. Italian Fascism was not inherently racist. By the time of the Racial Manifesto of 1938, over 10,000 or a third of Italian Jewish adults, including ministers and high officials appointed by Mussolini, were Fascist Party members: with the racial laws, Mussolini betrayed his 'most loyal subjects' (Thomson 2002: 80). ${ }^{21}$

In Austria-Hungary, too, Jewish patriotism was widespread both before and even after the collapse of the Habsburg Empire and the monarchy in World War I. The empire was fundamentally tolerant, with many different nationalities and ethnic groups. Jewish patriotism grew into a veritable cult after emancipation in 1867, when the Dual Monarchy of Austria-Hungary was formed. From then until World War I, the Jews made enormous educational and economic progress. Austrian Jews committed themselves totally to the 'sacred values' of religion, fatherland and the Kaiser. Despite anti-Semitism, the Austrian Jews asserted 'unshakeable dynastic loyalty and devotion' (Wistrich 1990: 175). In Hungary, similarly, many Jews 'passionately embraced Hungarian nationalism' (Silber 1992: 285). The Hungarian Jews were so thoroughly magyarized that anti-Semitism did not diminish their patriotism. Even after the empire collapsed and Austria and Hungary emerged as separate states, the Jews retained their loyalty, at times almost as though the empire still existed. When the Hungarian government passed anti-Semitic laws, the Jews remained attached to Hungary as 'Magyars of the Israelite Faith.' Even the racial laws of 1939 did not diminish Hungarian Jewish patriotism. ${ }^{22}$

\section{Jewish Patriotism in Eastern Europe}

Among East European Jews, more numerous, more victimized by anti-Semitism, surrounded in many cases by hostile, illiterate peasants, more immersed in tradition than their Western brethren, and less prone to self-hate, assimilation was generally viewed with wariness or abhorrence. Yet, as in Central and Western Europe, the East European Jewish leadership opposed emigration as unpatriotic, even when Jewish lives were threatened, for example in Russia at the time of the 1881 pogroms, Poland and Romania in the interwar period and Czechoslovakia after the signing of the Munich Agreement in September 1938.

\footnotetext{
${ }^{21}$ As elsewhere in Europe, Zionism prior to World War II was anathema to many patriotic Italian Jews. The Israeli diplomat, Dan Vittorio Segré, who grew up in Italy at this time, recalled: 'my father strongly opposed the Jewish national movement, which to his mind undermined the patriotism of the Italian Jews' (1988: 50).

22 On Hungarian Jewish patriotism at the time of the outbreak of war in 1939, see Patai $(1996: 541,554-5)$ and Braham (1994: 153).
} 


\section{Russia}

Tsarist Russia, which included two thirds of Poland, was the one major European centre where emancipation was seriously held back. Here were concentrated about 5 million Jews, the largest Jewish community in the world and one of the most persecuted and discriminated-against groups prior to 1917. Yet, even after the pogroms in 1881-1882, the assimilated Russian Jewish leadership was typically patriotic, and prominent Jews such as the financier Horace Günzburg and the Yiddish and Hebrew novelist Mendele Mocher Sefarim still believed that the future of the Russian Jews was in Russia. Though the Jewish masses generally loathed the anti-Semitic regime, tens of thousands of Russian Jews fought bravely in the Russo-Turkish War (1877-1878), the RussoJapanese War (1903-1904) and in World War I. It was mainly poverty that drove about two million Jews from Tsarist Russia in 1881-1914, mostly to America. The majority remained, many in the belief that Russia was destined to become more just and tolerant. The outbreak of war in 1914 triggered mass patriotic fever among the Russian Jews, as it did throughout Europe. Even the Jewish Socialist parties, which stressed the need for solidarity with the Russian workers, declared loyalty to Russia in its war effort (Zechlin 1969: 114). The involvement of many Jews in the socialist and revolutionary movements was motivated partly by their attachment to Russia and faith in Russia's future.

\section{Poland}

In Poland, too, many Jews were patriotic despite anti-Semitism. Love for and patriotic loyalty to the fatherland characterized the Polish Jewish community, numbering over three million (or about $10 \%$ of Poland's population), almost all of whom would be murdered. Yet, assimilated Jews often adopted attitudes of Polish Christians: some regarded Jewishness as a shameful disease. Many turned to the socialist Bund which opposed emigration and fought for equal rights for Jews (Shapiro 1994: 212). Polish Jews often hoped for national autonomy and for the creation of their own statesupported schools and communal administration (Berend 1998: 182). The patriotic attachment to Poland expressed by the poet Julian Tuwim in his poetry, though deeply personal and not without irony, was consistent with the history of the Polish Jews and also reflected a broad consensus in the interwar years, cutting across political divisions:

\section{Semitic blood flows in me}

Hot blood, passionate blood,

Oh, Aryans, I love you so much,

Oh Poland - the sun. You are my country. ${ }^{23}$

Diverse Jewish groups - the Hasidic rabbis of the Agudath Israel party, the atheistic Bund socialists, upper middle class Polish Jews with capital, skilled workers and even Zionists-hoped that by showing patriotic loyalty to Poland, they would justify their

${ }^{23}$ Aberbach (2013: 95). I am grateful to Professor Antony Polonsky for this translation. 
acceptance as Poles. ${ }^{24}$ Belief among the increasingly assimilated Polish Jews that they had a future in Poland continued even after 1933. Attempts by the Zionist leader Vladimir Jabotinsky in the late 1930s to organize mass emigration of Polish Jews came to nothing, even in the shadow of the German invasion: Polish Jewish opposition to emigration scuttled Jabotinsky's plan (Katz 1996: 1581). The official Jewish leadership was especially outraged by Jabotinsky, demanding his expulsion from Poland. Despite Polish anti-Semitism, there was a strong streak of patriotism among the increasingly assimilated Polish Jews, who identified with Polish culture and Polish political aspirations (Chajes 1998, Bader 1999). When war came in September 1939, many of the estimated 180,000 Jews conscripted into the Polish army-with over 30,000 casualties in fighting the German invasion-were motivated by patriotism for Poland (Meirtchak 2004: v, 15).

\section{Conclusion: Jewish Patriotism as Parody and Subversion}

What were the implications to national identity of the patriotism of European Jews in the 1789-1939 period? Patriotism was a natural reaction to emancipation or hope for emancipation, wherever Jews lived, whether in France, Germany, England or Italy in the West or in Russia, Poland, Hungary or Romania in the East. Yet, their patriotism also implicitly called into question the depth of any patriotic or national loyalty inasmuch as it was not part of the inalienable essence of a nation but could be learned and adopted, in many cases rapidly. Jewish assimilation into a host of national identities and even into the avant garde of national cultures conflicted with the notion of a fixed national identity, to which outsiders could not belong. If within a generation or two, East European Yiddish-speaking Jewish peddlers could be transformed throughout Europe (and elsewhere) into citizens indistinguishable from nonJews in appearance, language, behaviour and thought, how deep was national identity? Instead, Jewish patriotism in its international guises seemed to point to a common humanity, a universal determination to belong and to be accepted, and to the extraordinary capacity of human beings to change and adapt. To those - particularly Germans - who believed in fixed 'organic' national identity, such proof of the human potential for rapid and thorough change was as much a threat as the effects of the French and Russian revolutions were to European conservatives. Despite the growth of the secular state, anti-Semitism survived, both in traditional and new racial forms. As Jews were scattered throughout Europe, anti-Semites could always find them on the enemy side. ${ }^{25}$ Taken together, manifestations of Jewish patriotism throughout Europe were almost a parody of national identity. Hannah Arendt, who as a Zionist Organization official had worked with refugees in France in the 1930s before escaping to America, described bitterly in 1943 the tragic-comic patriotic transformations of an imaginary 'Mr. Cohn' from Berlin, 'a 150 percent German' who in 1933 found refuge in Prague where he became 'a convinced Czech patriot'; then, in 1937, when the Czech

\footnotetext{
${ }^{24}$ See, for example, Aberbach (2009b: 376-7), Davies (2005: ii 190), Lewin (1990: 116) and Mendes-Flohr and Reinharz (1995: 443).

${ }^{25}$ During the Franco-Prussian War of 1870-1871, the French branch of the Rothschilds allied itself with France, while Carl Meyer, head of the German branch, identified himself 'not only with Prussia but with the new German Reich proclaimed in the aftermath of the French defeat' (Ferguson 2000: 189).
} 
government expelled its Jewish refugees, he fled to Vienna where 'a definite Austrian patriotism' was required, but the Anschluss forced him to flee again to Paris, where though he could not get a residence permit, he nevertheless prepared himself for assimilation as a Frenchman by 'identifying himself with “our” ancestor Vercingétorix' (Arendt 2007: 271). Truth stranger than fiction was the sad case of German Jewish nationalists such as Max Naumann and Hans-Joachim Schoeps, who would have joined the Nazi Party had they been let in. Descendants of converted and assimilated Jews (including those of Moses Mendelssohn) fought in the Wehrmacht in World War II, and a small number even joined the SS (Rigg 2002: $60,64)$. Yet, the anonymous merging with the nation was not granted to most European Jews: 'France to the French, England to the English, America to the Americans, and Germany to the Germans' - this was how Hitler led up to his prophecy of the annihilation of the European Jews in his speech to the Reichstag on 30 January 1939 (Berenbaum 1997: 161). Their Jewish identity, even if long abandoned and forgotten, was wrenched from the past and presented to them as a death warrant.

Open Access This article is distributed under the terms of the Creative Commons Attribution 4.0 International License (http://creativecommons.org/licenses/by/4.0/), which permits unrestricted use, distribution, and reproduction in any medium, provided you give appropriate credit to the original author(s) and the source, provide a link to the Creative Commons license, and indicate if changes were made.

\section{References}

Aberbach, D. (2006). Nationalism, Reform Judaism and the Hebrew prayer book. Nations and Nationalism, 12(1), 139-159.

Aberbach, D. (2009a). Zionist patriotism in Europe, 1897-1942: ambiguities in Jewish nationalism. International History Review, 31(2), 268-298.

Aberbach, D. (2009b). Patriotism and antisemitism: the crisis of Polish Jewish identity between the wars. Polin, $22,368-388$.

Aberbach, D. (2013). The European Jews, 1789-1939: patriotism and the liberal state. London and New York: Routledge.

Aberbach, D. (2015). A one-sided love affair: German Jewish literature 1789-1939. Journal of Modern Jewish Studies, 14(3), 1-19.

Adler, J. (1987). The Jews of Paris and the final solution: communal response and internal conflicts, 1940-1944. New York \& Oxford: Oxford University Press.

Albanis, E. (2002). German-Jewish cultural identity from 1900 to the aftermath of the First World War. Tübingen: Niemeyer.

Anderson, B.. (1991)1983. Imagined communities: reflections on the origins and spread of nationalism (2nd ed.). London: Verso.

Arendt, H. (2007). In J. Kohn \& R. H. Feldman (Eds.), The Jewish writings. New York: Schocken Books.

Armstrong, J. (1982). Nations before nationalism. Chapel Hill: University of North Carolina Press.

Bader, Y. (1999). My way to Zion, 1901-1948. Autobiography. Jerusalem: Jabotinsky Institute.

Baron, S. W. (1962). From a historian's notebook. New York: The American Jewish Committee.

Berenbaum, M. (Ed.). (1997). Witness to the Holocaust. New York: Harper Collins.

Berend, I. T. (1998). Decades of crisis: Central and Eastern Europe before World War II. Berkeley, Los Angeles and London: University of California Press.

Berkovitz, J. R. (1989). The shaping of Jewish identity in nineteenth-century France. Detroit: Wayne State University Press.

Bialik, C.N. (2004). C.N. Bialik: selected poems (D. Aberbach, Ed. \& Trans.). Overlook Press/Duckworth.

Blake, R. (1967). Disraeli. London: Methuen.

Blom, J. C. H. (2002). Dutch Jews, Jewish Dutchmen and Jews in the Netherlands. In J. Israel \& R. Salverda (Eds.), Dutch Jewry: its history and secular culture (pp. 215-224). Leiden: Brill.

Braham, R. L. (1994). The politics of genocide: the holocaust in Hungary. In New York: Columbia University Press. Boulder: The Rosenthal Institute for Holocaust Studies/The City University of New York and Social Sciences Monograph. 
Breuilly, J. (1992). The state of Germany. London and New York: Longman.

Burns, M. (1999). France and the Dreyfus affair: a documentary history. Boston and New York: Bedford/St. Martin's.

Chajes, V. (1998). Diary of a Polish Jew. (P. Maizlish, Trans.). Ramat Gan: Bar Ilan University Press.

Chesnoff, R. Z. (1999). Pack of thieves: how Hitler and Europe plundered the Jews and committed the greatest theft in history. London: Weidenfeld \& Nicolson.

Cohen, J. (Ed.). (1996). For love of country: debating the limits of patriotism. Boston: Beacon Press.

Connor, W. (1994). Ethnonationalism: the quest for understanding. Princeton, NJ: Princeton University Press.

Davies, N. (2005). God's playground: a history of Poland. Oxford: Oxford University Press.

Deutsch, K. (1966). Nationalism and social communication. New York: MIT Press.

Doob, L. W. (2004). Patriotism and nationalism: their psychological foundations. New Haven, Connecticut: Yale University Press.

Dubnow, S. (1973). In M. Spiegel (Ed.), History of the Jews (Vol. 5). New York: Thomas Yoseloff Trans. from the Russian text of 1925-29.

Dwork, D., \& van Pelt, R. J. (2002). Holocaust: a history. New York: W.W. Norton.

Eisenbach, A. (1991 [1988]). The emancipation of the Jews in Poland,33-1970. A. Polonsky (Ed.). J. Dorosz (Trans.). Oxford: Basil Blackwell in association with the Institute for Polish-Jewish Studies

Endelman, T. M. (2002). The Jews of Britain, 1656 to 2000. London, Berkeley and Los Angeles: University of California Press.

Feiner, S. (2002). Haskalah and History. (C. Naor and S. Silverston, Trans.). Oxford and Portland, Oregon: The Littman Library of Jewish Civilization.

Ferguson, N. (2000). The House of Rothschild, the World's Banker, 1849-1998. Harmondsworth, Middlesex: Penguin Books.

Fleming, K. E. (2008). Greece: a Jewish history. Princeton: Princeton University Press.

Frankel, J. (1981). Prophecy and politics: socialism, nationalism, and the Jews, 1862-1917. Cambridge and New York: Cambridge University Press.

Friedländer, S. (1997). Nazi Germany and the Jews: the years of persecution 1933-39. London: Weidenfeld \& Nicolson.

Frister, R. (2002 [1999]). Impossible love: Ascher Levy's longing for Germany. (A. Jaffa, Trans.). London: Weidenfeld \& Nicolson.

Fuks-Mansfield, R.G. (2002). Arduous adaptation, 1814-1870. In J.C.H. Blom, et al. (Eds.), The History of the Jews in the Netherlands (A. J. Pomerans and E. Pomerans, Trans., pp. 192-229). Oxford and Portland, Oregon: The Littman Library.

Gellner, E. (1983). Nations and nationalism. Oxford: Blackwell.

Gilbert, M. (1987). The Holocaust: the Jewish tragedy. Glasgow: Fontana/Collins.

Golsan, R. J. (2010). Antisemitism in modern France: Dreyfus, Vichy, and beyond. In Lindemann and Levy (Eds.), Antisemitism: a history. Oxford University Press.

Green, A. (2010). Moses Montefiore: Jewish liberator, imperial hero. Cambridge Massachusetts and London, England: The Belknap Press of Harvard University.

Ha'am, A. (1953). Collected Works of Ahad Ha'am (Hebrew) . Dvir: Tel Aviv.

Habermas, J. (1992). Citizenship and national identity: some reflections on the future of Europe. Prax Int, 12(1), 1-18.

Hastings, A. (1997). The construction of nationhood: ethnicity, religion and nationalism. Cambridge and New York: Cambridge University Press.

Heller, C. S. (1977). On the edge of destruction: Jews of Poland between the two world wars. New York: Columbia University Press.

Herzl, T. (1896). Der Judenstaat (the Jewish state). Leipzig and Vienna: M. Breitenstein.

Hibbert, C. (2004). Disraeli: a personal history. London: Harper/Collins.

Hobsbawm, E.J. (1990). Nations and nationalism since 1780. Cambridge [England] and New York: Cambridge University Press.

Hutchinson, J. (1987). The dynamics of cultural nationalism. London: Allen \& Unwin.

Hyman, P. (1979). From Dreyfus to Vichy: the remaking of French Jewry, 1906-1939. New York: Columbia University Press.

Joll, J. (1960). Intellectuals in politics: three biographical essays. London: Weidenfeld and Nicolson.

Kaplan, M. A. (1992). The making of the Jewish middle class: women, family and identity in Imperial Germany. New York and Oxford: Oxford University Press.

Kaplan, M. A. (1998). Between dignity and despair: Jewish life in Nazi Germany. New York: Oxford University Press. Katz, S. (1996). Lone wolf: a biography of Vladimir (Ze'ev) Jabotinsky (Vol. 1-2). New York: Barricade Books. Kedourie, E. (1960). Nationalism. London: Hutchinson.

Klemperer, V. (2000). The diaries of Victor Klemperer 1933-1945: I shall bear witness to the bitter end. (Chalmers, M. Ed. \& Trans.). London: Phoenix Press.

Laqueur, W. (2003). A history of Zionism. London and New York: Tauris Parke/ EJPS. 
Leff, L. M. (2006). Sacred bonds of solidarity: internationalism in nineteenth-century France. Stanford, California: Stanford University Press.

Lewin, I. (1990). A history of Polish Jewry during the revival of Poland. New York: Shengold Publishers, Inc..

Liedtke, R., \& Wendehorst, S. (Eds.). (1999). The emancipation of Catholics, Jews and Protestants: minorities and the nation state in nineteenth-century Europe. Manchester and New York: Manchester University Press.

Macaulay, T. (1963). Macaulay's essays. Trevor-Roper, H. (Ed.). London and Glasgow: Collins/ Fontana.

Marrus, M. R. (1980). The politics of assimilation: a study of the French Jewish community at the time of the Dreyfus affair. Oxford: Clarendon Press.

Meirtchak, B. (2004). Jews-officers in the Polish armed forces 1939-1945 (2nd ed.). Tel Aviv: Solomon Levy Ltd..

Mendelsohn, E. (1983). The Jews of East Central Europe between the world wars. Bloomington: Indiana University Press.

Mendes-Flohr, P. R., \& Reinharz, J. (Eds.). (1995). The Jew in the modern world: a documentary history (2nd ed.). New York and Oxford: Oxford University Press.

Mikes, G. (1958). Über alles: Germany explained. London: Andre Deutsch.

Nathans, B. (2002). Beyond the pale: the Jewish encounter with late imperial Russia. Berkeley and Los Angeles: University of California Press.

Patai, R. (1996). The Jews of Hungary: history, culture, psychology. Detroit: Wayne State University Press.

Plessix Gray, F. du (2001). Simone Weil. London: Weidenfeld \& Nicolson.

Poliakov, L. (1985)1965. The history of anti-semitism (Vols. 1-4). (R. Howard et al. Trans.). New York: Vanguard Press.

Poppel, S. M. (1976). Zionism in Germany 1897-1933. Philadelphia: The Jewish Publication Society of America. Prawer, S. S. (1983). Heine's Jewish comedy. Oxford: Clarendon Press.

Proust, M. (1992 [1932-34]). In search of lost time (Vols. 1-6). (C.K. Scott-Moncrieff, et al. Trans.). London: Chatto \& Windus.

Pulzer, P. (1992). Jews and the German state: the political history of a minority, 1848-1933. Oxford: Blackwell.

Reinharz, J. (1975). Fatherland or promised land: the dilemma of the German Jew, 1893-1914. Ann Arbor: University of Michigan Press.

Rigg, B. M. (2002). Hitler's Jewish soldiers: the untold story of Nazi racial laws and men of Jewish descent in the German military. Lawrence, Kansas: University of Kansas Press.

Schama, S. (2005). Patriots and liberators: revolution in the Netherlands 1780-1813. London: Harper Perennial.

Segré, D. V. (1988). Memoirs of a fortunate Jew: an Italian story. London: Paladin.

Seton-Watson, H. (1977). Nations and states. London: Methuen.

Shapiro, R. M. (1994). The Polish Kehillah elections of 1936: a revolution re-examined. In A. Polonsky, E. Mendelsohn \& J. Tomaszewski (Eds.) Polin, (Vol. 8: pp. 206-226). London and Washington: The Littman Library of Jewish Civilization.

Sieg, U. (2003). Nothing more German than the German Jews? On the integration of a minority in a society at war. In R. Liedtke \& D. Rechter (Eds.), Towards normality? Acculturation and modern German Jewry (pp. 201-216). Tübingen: Mohr Siebeck.

Silber, M. K. (1992). The entrance of Jews into Hungarian society in Vormartz: the case of the 'casinos'. In J. Frankel \& S. J. Zipperstein (Eds.), Assimilation and community: the Jews in nineteenth-century Europe (pp. 284-323). Cambridge and New York: Cambridge University Press.

Smith, A. D. (1991). National identity. Harmondsworth, Middlesex: Penguin.

Stern, F. (1987). Dreams and delusions: the drama of German history. London: Weidenfeld \& Nicolson.

Toller, E. (1934). I was a German: an autobiography. (E. Crankshaw, Trans.) London: John Lane, The Bodley Head.

Thomson, I. (2002). Primo Levi. London: Hutchinson.

Viroli, M. (1995). For love of country: an essay on patriotism and nationalism. Oxford: Clarendon Press.

Volkov, S. (2006). Germans, Jews and Antisemites. Cambridge and New York: Cambridge University Press.

Wassermann, J. (1921). Mein Weg als Deutscher und Jude (my way as German and Jew). Berlin: Fischer.

Weber, E. (1985). Reflections on the Jews in France. In F. Molino \& B. Wasserstein (Eds.), The Jews in modern France (pp. 8-27). Brandeis University Press and University Press of New England: Hanover \& London.

Weinbaum, L. (1993). A marriage of convenience: the new Zionist organization and the Polish government 1936-1939. Boulder: East European Monographs, distributed by Columbia University Press, New York.

Winock, M. (1998) [1982]. Nationalism, anti-semitism, and fascism in France. (J. M. Todd, Trans.). Stanford, California: Stanford University Press.

Wistrich, R. S. (1990). The Jews of Vienna in the age of Franz Joseph. Oxford and New York: The Littman Library of Oxford University Press.

Zechlin, E. (1969). Die Deutsche Politik und die Juden im Ersten Weltkrieg (German politics and the Jews in World War I). Göttingen: Wandenhoeck \& Ruprecht.

Zeldin, T. (1977). France 1848-1945. Oxford: Clarendon Press. 
Zohn, H. (1985). Fin-de-Siécle Vienna: The Jewish contribution. In J. Reinharz and W. Schatzberg (Eds.), The Jewish response to German culture: from the Enlightenment to the Second World War (pp. 137-149). Hanover: University Press of New England for Clark University.

Zweig, R. W. (2002). The gold train: the destruction of the Jews and the Second World War's most terrible robbery. London: Allen Lane, Penguin Books. 